\title{
Budidaya Ikan Lele (Clarias SP) Dengan Sistim Kolam Bioflok Pada Pokdakan Tanah Berongga-Sido Urep
}

\author{
Imam Hadi Sutrisno ${ }^{*}$, Baihaqi ${ }^{2}$, Zidni Ilman Navia ${ }^{3}$ \\ ${ }^{1,2}$ Fakultas Keguruan dan Ilmu Pendidikan, Universitas Samudra \\ ${ }^{3}$ Prodi MIPA Biologi Fakultas Teknik, Universitas Samudra \\ email: hadi_sutrisno@unsam.ac.id
}

\begin{abstract}
The proposed community service (PKM) aims to develop a biofloc system in catfish farming at Pokdakan Tanah Berongga-Sido Urep. The goal of the activity is providing new knowledge about catfish cultivation with a biofloc system. The target of this program is Pokdakan Tanah BeronggaSido Urep. The main problem faced by the group is the catfish activities are still carried out conventionally using ground and stone ponds. These activities like affected to on environmental distruction especially the soil structure that has been eroded by the cultivation activities. The activities carried out such as: 1) Socialization of catfish culture with a biofloc system, 2) Provision of tools and materials for the manufacture of biofloc ponds, 3) Training for making biofloc ponds, 4) Distribution of catfish seedlings in biofloc ponds, 5) Catfish enlargement in biofloc ponds and 6) Harvesting catfish. The PKM team will also provide assistance during the activity. At the end of the activity, an evaluation and follow-up action plan (RTL) will be carried out so that the business carried out by partners can continue so that an independent business group can be realized
\end{abstract}

Keywords: Catfish Cultivation, Biofloc System, Pokdakan Tanah Berongga-Sido Urep

\begin{abstract}
Abstrak
Pengabdian kepada masyarakat (PKM) yang diusulkan bertujuan untuk mengembangkan sistem kolam bioflok dalam budidaya ikan lele pada kelompok pembudidaya ikan (Pokdakan) Tanah Berongga-Sido Urep. Tujuan kegiatan ini adalah memberikan pengetahuan baru tentang budidaya lele dengan sistem bioflok. Sasaran program ini adalah Pokdakan Tanah Berongga-Sido Urep. Permasalahan utama yang dihadapi oleh kelompok adalah selama ini kegiatan budidaya ikan lele masih dilakukan secara konvensional dengan menggunakan kolam tanah dan batu. Kegiatan budidaya seperti ini berdampak terhadap kerusakan lingkungan terutama struktur tanah yang tergerus oleh kegiatan budidaya itu. Kegiatan yang akan dilaksanakan meliputi: 1) Sosialisasi budidaya ikan lele dengan sistem kolam bioflok, 2) Penyediaan alat dan bahan untuk pembuatan kolam bioflok, 3) Pelatihan pembuatan kolam bioflok, 4) Distribusi benih ikan lele pada kolam bioflok, 5) Pembesaran ikan lele pada kolam bioflok dan 6) Pemanenen ikan lele. Tim PKM juga akan melakukan pendampingan selama kegiatan berlangsung. Pada akhir kegiatan, akan dilakukan evaluasi dan pembuatan rencana tindak lanjut (RTL) agar usaha yang dilakukan oleh mitra dapat berlanjut sehingga dapat terwujud kelompok usaha yang mandiri
\end{abstract}

Kata Kunci: Ikan Lele, Kolam Bioflok, Pokdakan Tanah Berongga-Sido Urep

\section{PENDAHULUAN}

Pokdakan Tanah Berongga Sido Urep didirikan pada bulan Juni tahun 2012, namun baru mendapatkan SK Dinas Kelautan dan Perikanan (DKP) kabupaten Aceh Tamiang pada bulan Oktober 2013 dengan jumlah anggotanya berjumlah 35 orang. Nugraha dkk (2014) menjelaskan inisiatif pembentukan kelompok ini berawal dari permasalahan ekonomi masyarakat dengan $76 \%$ keluarga didusun Makmur adalah miskin. Anggota kelompok melakukan analisis potensi wilayah yang ada di dusun Makmur dengan tanah berongga yang merupakan jenis tanah liat berwarna putih keras 
merekah dan tanah ini tidak kering pada musim kemarau, dengan kondisi tersebut kelompok Pokdakan Tanah Berongga membuat kawasan pembudidayaan ikan Lele dengan sistem kolam tanah, kolam terpal dan kolam semen. Perkembangan Pokdakan ini mengalami kemajuan sangat pesat, seiring anggota kelompok mendapatkan pelatihan dan pendampingan dari berbagai perusahaan dan instansi. Saat ini Pokdakan Tanah Berongga-Sido Urep memiliki 200 kolam terdiri atas 30 kolam pembenihan, 8 kolam batu untuk pembesaran dan 162 kolam tanah untuk pembesaran ikan lele. Omset penjualan ikan lele perbulan yang diperoleh oleh anggota kelompok sebanyak Rp. 4.500.000/bulan. Keseluruhan anggota kelompok melakukan budidaya ikan lele menggunakan kolam tanah berdampak buruk terhadap penataan lingkungan. Untuk meminimalisir kelemahan yang dialami oleh anggota kelompok dalam kegiatan budidaya ikan lele, diperlukan adanya sistem budidaya ikan lele yang efektif meningkatkan produktifitas, mempercepat masa panen dan mengurangi penggunaan lahan lebih luas yang dikenal dengan sistem budidaya bioflok. Faridah dkk (2019) menyebutkan bahwa pembesaran ikan lele yang inovatif dan produktif adalah melalui sistim bioflok. Sementara Sudaryati dkk ( 2017) menyebutkan bahwa sistem bioflok merupakan metode budidaya ikan lele yang sudah cukup modern, teknologi ini sekarang sudah banyak dipakai oleh para pembudidaya ikan lele karena mampu mengurangi biaya produksi. Sistem bioflok ini dinilai efektif dan mampu mendongkrak produktivitas. Ini karena dalam kolam yang sempit dapat diproduksi lele yang lebih banyak. Dengan begitu, biaya produksi berkurang dan waktu yang diperlukan relatif lebih singkat jika dibandingkan dengan budi daya secara konvensional.

Pada penjelasan lainnya, Setiawan dkk (2016) mengungkapkan bahawa sistim bioflok dapat dilakukan tanpa pergantian air dan kontrol ekologinya adalah berupa bakteri bioflok yang dikondisikan, tidak bergantung dari sinar matahari, menggunakan bahan organik serta aerasi penuh dan kuat. Sedangkan Gemaperta (2015) menyebutkan keistimewaan sistim kolam bioflok waktu budidaya relatif singkat, modal relatif rendah, ramah lingkungan dan hemat penggunaan air dan pakan.

\section{METODE PENGABDIAN}

Metode yang akan digunakan untuk pelaksanaan kegiatan ini adalah dengan model Participatory Rural Appraisal yaitu sutau metode pendekatan dalam proses pemberdayaan dan peningkatan partisipasi masyarakat yang penekanannya pada keterlibatan masyarakat dalam keseluruhan kegiatan yang dilaksanakan. Adapun tahapan kegiatan pengabdian kepada masyarakat yang dilakukan adalah sebagai berikut: koordinasi kegiatan dalam rangka menyampaikan rencana pelaksanaan kegiatan untuk kelompok sasaran. Tim pelaksana PKM menjelaskan secara detail rincian dan jadwal kegiatan kepada kepala desa, Ketua dan anggota Pokdakan Tanah Berongga-Sido Urep serta masyarakat kampung kebun tanjung seumantoh. Kemudian tahap selanjutnya adalah sosialisasi kegiatan yang bertujuan memberikan informasi secara menyeluruh kepada pihak pihak yang terlibat dalam kegiatan ini dengan metode diskusi langsung. Tahapan berikutnya adalah penyerahan bahan habis pakai berupa peralatan untuk pembuatan dua unit kolam bioflok berukuran 3 meter. Selanjutnya tahapan pendampingan berupa pembuatan 2 (dua) unit kolam bioflok secara swadaya oleh masing-masing anggota kelompok selama dua minggu serta terakhir tahapan monitoring dan evaluasi untuk memastikan kegiatan pengabdian kepada masyarakat berjalan sesuai dengan target yang direncanakan. 


\section{HASIL DAN PEMBAHASAN}

Kegiatan pengabdian budidaya ikan lele dengan sistim kolam bioflok diikuti oleh seluruh anggota kelompok dan juga dihadiri oleh perangkat desa.

A. Tahapan Sosialisasi

Dalam tahapan sosialisasi ini tim pengabdi bersama dengan mitra sasaran kegiatan menyepakati mekanisme kerja bersifat. Kegiatan ini turut dihadiri oleh kepala desa dan sekretaris desa selaku aparatur pemerintahan kampung yang berharap akan adanya kegiatan lanjutan pada tahap berikutnya bukan saja bagi pokdakan tanah berongga-sido urep namun juga bagi kelompok masyarakat lainnya seperti kelompok tani, kelompok ibu-ibu, remaja dan juga bagi perangkat kampung.

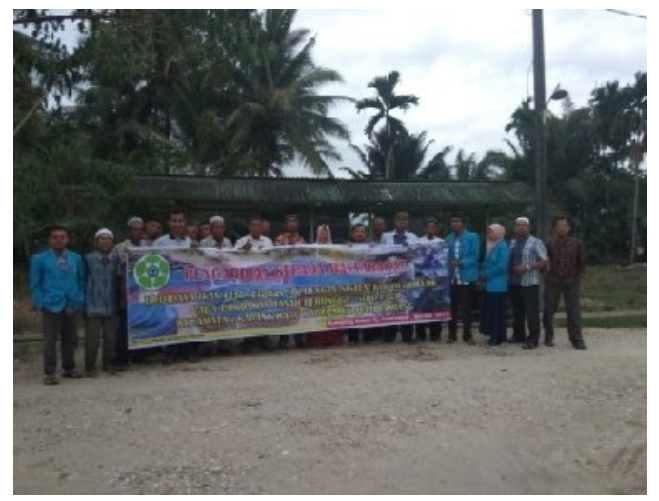

Gambar 1. Sosialisasi Kegiatan

B. Serah Terima Bahan Habis Pakai

Untuk menunjang pelaksanaan kegiatan pengabdian kepada masyarakat di pokdakan tanah berongga-sido urep, tim pengabdi telah menyerahkan bahan habis pakai berupa 5000 benih ikan lele ukuran 3 inc, semen, pasir, kerikil, besi ulir, seng plastik, terpal, airator, selang air, pakan pelet ukuran 781-1, PF-1000 sebanyak 40 $\mathrm{Kg}$, PF-1 sebanyak $20 \mathrm{Kg}$, 781-2 sebanyak $80 \mathrm{~kg}$ dan 781-polos sebanyak $15 \mathrm{~kg}$, molase dan EM4
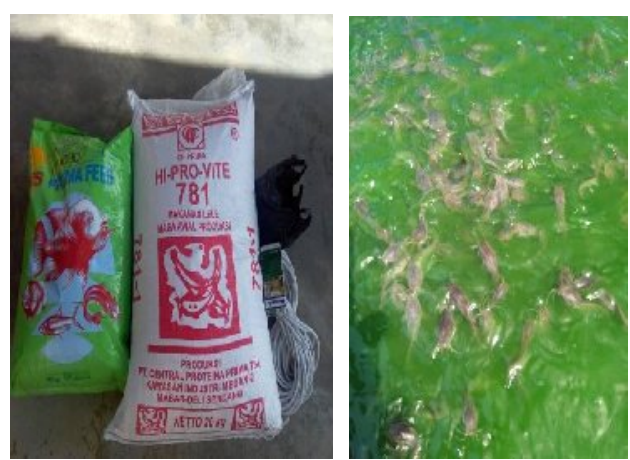

Gambar 2. Bahan Habis Pakai

\section{Pembuatan Kolam Bioflok}

Tim PKM bersama dengan mahasiswa dan anggota pokdakan tanah berongga-sido urep mulai membuat 2 (dua) unit kolam bioflok dengan jangka waktu penyelesaian 2 (dua) minggu. Pembuatan kolam bioflok ini dilakukan secara swadaya dengan melibatkan seluruh anggota kelompok serta turut diawasi oleh kepala desa bersama dengan ketua pokdakan tanah berongga-sido urep. Dalam kegiatan ini, tim PKM juga mencatat tahapan pembuatan kolam bioflok sebagai bahan evaluasi kegiatan paska pendampingan bagi kelompok sasaran berakhir.

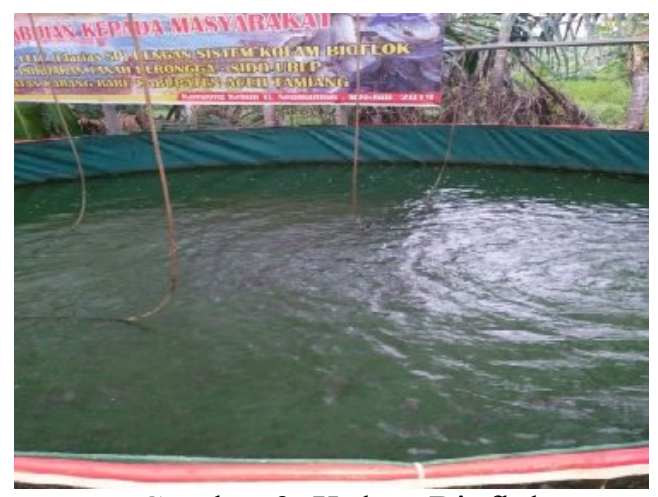

Gambar 3. Kolam Bioflok

D. Monitoring Kegiatan Pengabdian Kepada Masyarakat (Tahap I)

Tim PKM Universitas Samudra melakukan monitoring tahap I pada pokdakan tanah berongga-sido urep dalam rangka memastikan kegiatan PKM berjalan dengan baik. Kegiatan monitoring di fokuskan pada kolam bioflok yang 
digunakan untuk budidaya ikan lele dengan jumlah benih yang ditebar pada kedua kolam tersebut sebanyak 5000 ekor. Keseluruhan benih merupakan hasil pemijahan dari kelompok itu sendiri dengan masa panen ditargetkan pada hari ke 75 s.d 90 sesuai dengan siklus budidaya ikan lele. Hasil penjualan ikan lele dimasukkan kedalam kas kelompok. Hasil monitoring menunjukkan bahwa ukuran benih ikan lele sudah mencapai $5 \mathrm{~cm}$ dan semuanya dalam kondisi baik dengan tingkat kematian yang rendah. Pakan yang digunakan adalah pelet ukuran 781-1 dan PF-1000 sebanyak $40 \mathrm{Kg}$, PF-1 sebanyak $20 \mathrm{Kg}, 781-2$ sebanyak $80 \mathrm{~kg}$ dan 781polos sebanyak $15 \mathrm{~kg}$. Sesuai dengan pengalaman dalam pembudidayaan ikan lele sistim kolam bioflok, jadwal pemberian pakan adalah 2 (dua) kali sehari yakni pada pagi dan sore hari dikarenakan salah satu faktor pembeda budidaya ikan lele pada kolam bioflok dengan kolam tanah atau semen adalah berkenaan dengan pakan dimana pada kolam bioflok pakan yang digunakan adalah 100\% pakan pelet.

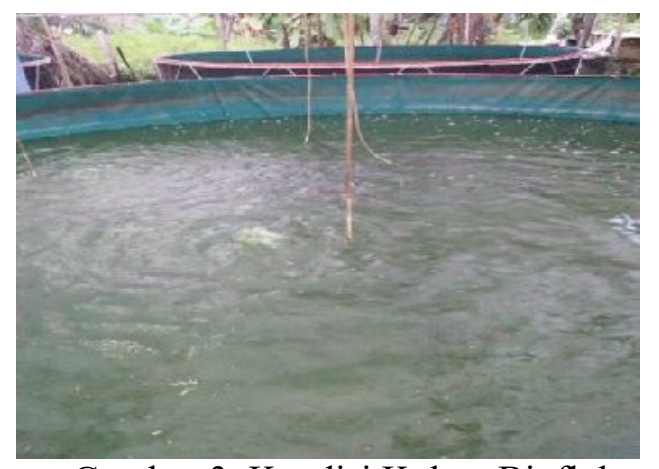

Gambar 3. Kondisi Kolam Bioflok

E. Monitoring Akhir Kegiatan
Pengabdian Kepada Masyarakat
Tim Pengabdi Universitas Samudra melakukan monitoring akhir sekaligus mengevaluasi kegiatan pengabdian pada pokdakan tanah berongga-sido urep. Hasil monitoring dan evaluasi dicatat pada lembaran catatan harian sebagai bagian dari pelaporan akhir kegiatan pengabdian kepada masyarakat. Berdasarkan hasil pengamatan dan diskusi dengan pengurus pokdakan tanah berongga-sido urep tidak ditemukan kendala dalam pelaksanaan kegiatan PKM ini. Ukuran benih ikan lele yang terpantau sudah mencapai 8-10 inch dengan tingkat kematian 10\%. Ketua pokdakan tanah berongga-sido urep mengungkapkan bahwa berdasarkan hasil perkembangan budidaya ikan lele pada kolam bioflok hasil panen diprediksi mencapai 450 s.d $500 \mathrm{~kg}$ sesuai dengan jumlah benih yang ditabur sebanyak 5000 ekor. Hasil panen yang diperoleh disepakati untuk menambah kas pokdakan tanah berongga-sido urep sehingga uang kas dapat digulirkan kembali kepada anggota pokdakan lainnya. Pokdakan tanah berongga-sido urep berharap adanya kegiatan lanjutan yang dapat dilakukan oleh Universitas Samudra seperti pembuatan mesin pelet, mesin pakan automatis, penambahan kolam bioflok, penatausahaan administrasi dan keuangan kelompok serta produk olahan berbahan lele bagi ibu-ibu anggota kelompok

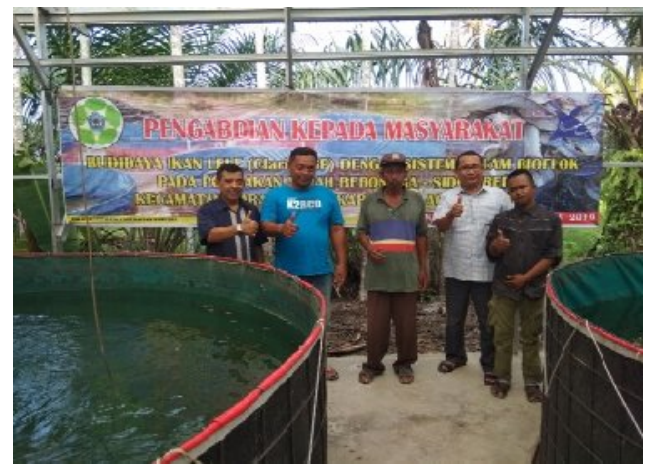

Gambar 4. Monev Kegiatan PKM

\section{SIMPULAN}

Berdasarkan pelaksanaan kegiatan pengabdian kepada masyarakat dapat disimpulkan bahwa:

a. Tahapan pelaksanaan kegiatan pengabdian kepada masyarakat pada Pokdakan Tanah Berongga-Sido Urep dimulai dari tahap sosialisasi kegiatan, pembelian bahan habis pakai (BHP) kepada mitra I, pendampingan pembuatan kolam bioflok, monitoring dan evaluasi 
pelaksanaan kegiatan pengabdian kepadamasyarakat.

b. Jumlah kolam bioflok yang dirancang adalah sebanyak 2 (dua) unit dengan ukuran $3 \times 3$ meter serta jumlah benih yang didistribusikan untuk kegiatan budidaya ikan lele dengan sistem kolam bioflok adalah sebanyak 5000 ekor berukuran masing-masing 3 inc dimana setiap kolam ditabur 2500 ekor benih ikan lele sesuai dengan besaran kolam bioflok itu

c. Hasil monitoring yang dilakukan oleh tim PKM Universitas Samudra dua minggu paska penebaran benih ikan lele pada 2 kolam bioflok, ukuran benih ikan lele telah mengalami pembesaran menjadi 7-8 inch. Pokdakan tanah berongga-sido urep memprediksi bahwa masa panen ikan lele hari ke 75 s.d ke 90 dengan targetnya $450 \mathrm{~kg}$ s.d $500 \mathrm{~kg}$ dengan harga jualnya Rp. 17.000/kg

d. Keseluruhan keuntungan yang didapatkan dalam budidaya ikan lele dengan sistim kolam bioflok dimasukkan kedalam kas kelompok untuk menambah asset kelompok dan dapat digulirkan kepada anggota kelompok lainnya

\section{UCAPAN TERIMAKASIH}

Penulis ucapkan terima kasih kepada Lembaga Penelitian, Pengabdian Kepada Masyarakat dan Penjaminan Mutu (LPPM) Universitas Samudra yang telah mendanai kegiatan pengabdian kepada masyarakat (PKM) tahun 2019 dengan No. kontrak 386/UN54.6/PM/2019 tanggal 11 April 2019. Penulis juga mengucapkan terima kasih kepada Pemerintahan Kampung Kebun Tanjung Seumantoh, Pokdakan Tanah BeronggaSido Urep dan Pokhlasar Makmur Sejahtera Kampung Kebun Tanjung Seumantoh, Kecamatan Karang Baru, Kabupaten Aceh Tamiang

\section{DAFTAR PUSTAKA}

[1]. Dinas Kelautan dan Perikanan Kabupaten Aceh Tamiang 2019.

[2]. Faridah, Diana, S, Yuniati. Budidaya Ikan Lele Dengan Metode Bioflok Pada Peternak Ikan Lele Konvensional. CARADDE: Jurnal Kepada Masyarakat. Vol. 1 No. 2, Februari 2019. https://doi.org/10.31960/caradde.vli2.74.

[3]. Gemaperta. 2015. Cara Budidaya Ikan Lele dengan Sistem Bioflok. http://www.gemaperta.com/2015/02/cara budidaya-ikan-lele-dengan-sistembioflok.html

[4]. Nugraha, Iswantara Adi, Baihaqi, Agus Nur Aji, Sugiono, Dedi Zikrian. 2014. "Si Kumis Pembawa Berkah" Best Practice Program CSR PT Pertamina EP-Field Rantau Dalam Pengembangan Budidaya Lele di Dusun Makmur Kampung Kebun Tanjung Seumantoh Kecamatan Karang Baru Kabupaten Aceh Tamiang". Jakarta: CV Global Express

[5]. Setiawan, Ariqoh, R, Tivani, P, Pipih, L. Pudjiastuti, I. Bioflokulasi Sistem Teknologi Budidaya Lele tebar Padat Tinggi Dengan Kapasitas 1 m3/750 ekor Dengan Flock Forming Bacteria. Inovasi Teknik Kimia, Vol. 1. No. 1, April 2016 Hal: 45-49

[6]. Sudaryati, D, Heriningsih, S, Rusherlistyani. Peningkatan Produktivitas Kelompok Tani Ikan Lele Dengan Teknik Bioflok. Jurnal Pengabdian dan Pemberdayaan Masyarakat Volume 1 No. 2 September 2017. 